\title{
Inevitable mother-baby separation in the immediate postpartum from a maternal perspective
}

Bruna Figueiredo Manzo 1

Anna Caroline Leite Costa 2

Miriã Diniz Silva 3

Danúbia Mariane Barbosa Jardim 4

Laiana Otto da Costa 5

\footnotetext{
1-3 Departamento de Enfermagem Materno Infantil e Saúde Pública. Escola de Enfermagem. Universidade Federal de Minas Gerais. Av. Prof. Alfredo Balena, 190. Santa Efigênia. Belo Horizonte, MG, Brasil. CEP: 30.130-100. E-mail:brunaamancio@yahoo.com.br

4,5 Hospital Sofia Feldman. Belo Horizonte, MG, Brasil.
}

\begin{abstract}
Objectives: to understand the process of inevitable mother-baby separation in the immediate postpartum from a maternal perspective.

Methods: this is a qualitative approach research study developed by interviewing 15 mothers who were separated from their children in the postpartum at a public maternity hospital in Belo Horizonte, Minas Gerais, Brazil. The analysis content was used for data interpretation.

Results: the categories were evidenced through "Maternal feelings and perceptions regarding to the child's separation in the postpartum period" and "Women's perception about health professionals' performance at the time of the separation and the presence of their companions", the contradictions of feelings and challenges experienced by the mothers due to the separation as for, the happiness of her child's birth followed by the anguish of being separated and the fear of losing her child.. The healthcare team plays a relevant role regarding the difficulties and helps to overcome these challenges.

Conclusions: advances in healthcare actions are needed in order to offer directed care to the real necessities of these mothers and decrease the negative impacts caused by this separation.

Key words Obstetric nursing, Maternal-fetal relationship, Humanized childbirth, Obstetric labor complications
\end{abstract}

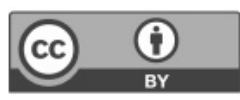




\section{Introduction}

The gestation and the birth of a child are social events that permeate the woman's reproductive experience and results in a remarkable moment in the lives of those who participate in this context. This experience is composed by physical, psychological, economic and social alterations that do not only restrict at the moment of childbirth, but also involves inter and trans generational legacies, the companion, the family and the community. ${ }^{1,2}$

From a mother's point of view who gives birth, the immediate postpartum period is considered to be the attachment to the precursor. Thus, this is the mother's first opportunity to be moved by her baby and begin a social exercise of motherhood, drawing the gestational process into a closure. 3

The woman experiences the psycho-organic adaptations in the puerperium period. In some cases, her negative experiences and emotional instabilities may contribute to develop pathological situations, such as postpartum depression, rejection of the child and self-image disturbances. ${ }^{4}$ Therefore, the consolidation of the affective bonds among the mother and child and their relatives contribute to prevent such disorders and diseases. 4

In order to improve the women's quality of care during this period of instability, the Ministério da Saúde (MS) (Brazilian Ministry of Health) instituted the Programa de Humanização no Pré-Natal e Nascimento (PHPN) (Humanization on Prenatal and Childbirth Program) in 2000, which has as the main objective in reducing maternal and perinatal morbidity and mortality rates to expand prenatal care access and to ensure the quality and humanization in childbirth and puerperium care. 5

Thus, researchers in the field emphasize the necessity to promote quality in care during pregnancy puerperal process by seeking humanization in childbirth. 5 Within this perspective emerges the concerns of newborns receiving respect and affection as well as caring for the mother's needs at the moment. 6

One of the strategies that is along the line with these assumptions is the skin-to-skin contact between the mother and child right after birth. This contact benefits the affective bond between the mother and child and determines relevant outcomes to the maternal physiological processes, such as placental expulsion, reduction of lochia, breast milk production and breastfeeding stimulation, as well as reducing the impact and shock caused by the differences between the intra and extra uterine world.4,7

Therefore, the Ministério da Saúde (MS),
(Ministry of Health) established guidelines for the organization to have integral and humanized care for newborns (NB) in the Sistema Único de Saúde (SUS) (National Health System), and advocated that immediate and continuous skin-to-skin contact should be ensured for all healthy NBs' cases. 5 However, it should be emphasized that some children who are born healthy have suffered with the separation of their mothers for no reasons at all by healthcare professionals, in the contrary of the logical integral and humanized care.

In special situations of maternal and neonatal complications arose from a high-risk pregnancy or not, might have affected the baby's vitality. This fact may prevent skin-to-skin contact and interfere with the woman's role as a new mother. ${ }^{8}$ In this situation, the newborn is usually separated from the mother in order to be checked and, if necessary, is submitted to medical interventions performed by the healthcare team. This type of separation is the focus of this study.

In cases where skin-to-skin contact is impossible to be offered directly after delivery, it is important that it should be offered as soon as the mother and child are physically and emotionally recovered and should be prolonged in order to meet the necessities for both parties. Therefore, all those involved must make an effort to maintain this bond that started in since the gestation. 6

Healthcare professionals working in labour and childbirth process have an important role to encourage and stimulate early contact between mother and child, offering an integral care that includes the establishment of physiological homeostasis, but also meets the demands related to female subjectivity and the meaning of motherhood.2,3

The relevance of this study is due to the recurrence of premature births or of clinically unstable newborns, which in many cases result in the inevitable mother and baby separation. Thus, to understand this experience it is fundamentally important to humanize care and give support according to the necessities presented by these women.

The production of knowledge within this context is necessary to strengthen Public Health Policies that prioritizes care for woman, newborn and the family in this unlikely and unpredictable period. This study aims to understand the process of inevitable mother and baby separation in the immediate postpartum period from a maternal perspective. 


\section{Methods}

This is a descriptive study with a qualitative approach capable of revealing social processes, constructing new approaches, reviewing and creating concepts and categories during the investigation working with meanings, values and attitudes, which corresponds to profound relationships, processes and phenomena that cannot be reduced to the operationalization of the variables. 9

This research was developed in a philanthropic public maternity hospital in Belo Horizonte in integral care provided by the Sistema Único de Saúde (SUS) (National Health System). According to the indicators at the institution, in $2015,11,473$ childbirths were performed, $78 \%$ were natural births performed by obstetric nurses and $22 \%$ were assisted by an obstetrician. The cesarian section rate was $24 \% .10$ This scenario should be emphasized that a protocol ensures that healthy neonates should stay with their mothers immediately after birth and they should not be separated.

The participants of this study were 15 mothers who were separated from their babies right after childbirth due to the baby's unbalanced vitality. Mothers who experienced the separation of their child in the immediate postpartum were included in this study. No mothers refused to participate in the study. In order to define the number of interviewed subjects, data saturation was used in order to cease the inclusion of new participants, which according to the researcher, at the moment when there had already been an understanding of the investigated phenomenon, the collected data presented redundancy. 11

The data collection was performed from December 2014 to January 2015 and it was guided by interviews with a semi-structured script. The patients' medical records were also used to collect information on the reasons for the separations and the women's clinical history. The interviews were recorded and afterwards transcribed and analysed according to the methodological referral on qualitative analysis content. This type of analysis presents a wide applicability and allows integrated techniques to be used, including interpretive and intuitive approaches. 12 This is defined as a research method used for analysis and the subjective interpretation of a phenomenon was not yet sufficiently studied but maintained the scientific rigor.

In its conventional modality, the categories derived from the data were obtained from the interviews, bringing direct information from the subjects' content. Three distinct phases are presented: pre- analysis, material exploration and treatment of the results. ${ }^{12}$ The pre-analysis phase is developed to systematize the initial ideas and to establish indicators for the interpretation of the collected data. Once the first phase is completed, the material exploration begins in the second phase and is constituted when the coding operations are constructed, considering the clippings of texts in the registration units and the aggregation of information in symbolic or thematic categories. The third phase understands the treatment and the interpretation of the results constitutes in obtaining the verified manifesto contents in the interviews. 12

In order to provide the participant's anonymity, the interviewees were coded by using the letter A, followed by a number to represent the participation order which ranged from 1 to 15 , for example: A1 (Interviewee 1). This study respects the ethical principles and was approved by the Ethics and Research Committee of the institution, under the CAAE document no: 33611314.5.0000.5132.

\section{Results}

The 15 interviewees' profile were all women $(100 \%)$, of these 15 , seven were experiencing motherhood for the first time - except for one who had a previous abortion - while the other eight had two or more children. The age of the sample ranged from 20 to 26 years old, and all had complete high school level. All the participants stated that their pregnancy was planned, they had participated in prenatal care and lived with their companions. Among the 15 participants, 10 had normal childbirths and 5 had cesarian sections.

We should emphasize that these mothers were separated from their babies after childbirth due to their child's hemodynamic and/or respiratory instability. The most prevalent cause of instability was due to prematurity and the baby's non-reassuring fetal state, which occurs when there is an interruption in the oxygen transference from the environment to the fetus. ${ }^{13}$

According to the analysis of the interviews, it was possible to apprehend the following categories: 1) The mother's feelings and perceptions regarding the separation of the child in the postpartum period and 2) The women's perception regarding the health professionals' performance and their companions' presence. 
The mother's feelings and perceptions regarding the separation of the child in the postpartum period

The interviewees expressed their desire to experience motherhood, followed by the disrupted expectation in being separated from the child after childbirth, as it can be observed in the following statement:

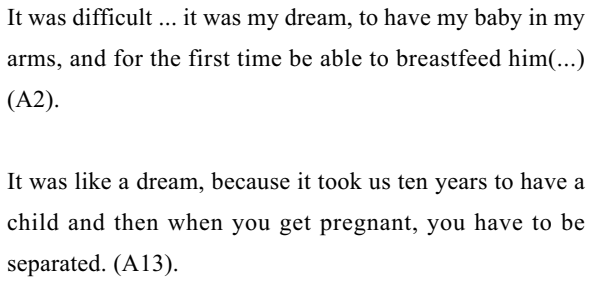

It was like a dream, because it took us ten years to have a child and then when you get pregnant, you have to be separated. (A13)

On the other hand, when the dream does not come true and the outcome was not what they expected, so feelings begin to arise, such as frustration, sadness and anguish due to the disrupted expectations that were created. This feeling was obvious in the following statement:

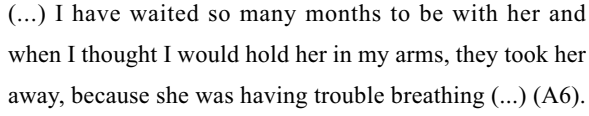

(...) I thought that when she was born we were able to stay with her... until now I still feel the emptiness... oh my, I didn't even hear her first cry, because she didn't even cry in the delivery room (A11).

The mothers expressed the feeling of anguish because they were not able to experience the moment of having their child in their arms because the healthcare team needed to perform medical interventions:

(...) I saw her crying and they took her to a different place and started to clean her up, then quickly they put her by my side, but as I couldn't lift my head, you know, I saw her but I didn't see her very well and it was very fast, and so, it was very bad. I had a different expectation, I expected to be able to hug her (A6).

In this context, the mothers emphasize that, in addition to the desrupture of the expectation to remain with her baby after childbirth, there was also the feeling of anguish related to the fear of losing their children, as reported below:

(...) I thought, I'm losing my son (...) I don't wanna lose him (...) I was very scared, I was just imagining, crying, asking God to save my child (A4).

In addition to the fear of losing, there was also an intense concern and uncertainties regarding the unknown, as it can be observed in the statements:

The first thing I asked was how is my son? People, talk to me for the love of God, talk to me!! (A4)

(...) it causes a strange feeling, oh my, what's going to happen to them now, I won't know until I go up there (...) I was very scared, I just wanted to know what they were going do with the boys (A5).

I was worried that she would die, my God, she is my first daughter (A14).

The women's perception regarding to the health professionals' performance at the moment of the separation and their companions' presence

We noted that the way in which the mother and baby are cared for by the health professionals, result in a less traumatic separation for both parties, as we can observe in this statement:

I just wanted him close by, right? But he was well treated, thank God, he was taken to the ICU, it was all very fast for him, thank God he is okay (...) (A6).

(...) we see everyone with their babies in their arms, I also wanted to have mine in my arms, but she is much better there (ICU) so, I hope she will be with me soon. (A8).

In the statements, it is noticed that even the transfer of the child to the intensive care unit, which is considered a place for patients at risk of death, may ease the reflexes when the care is performed in a respectful way.

However, in some reports, maternal insecurities and doubts regarding to the invasive procedures performed on the baby were perceived, as reported below:

(...) when I saw them putting her in a hood (...), like, I was scared (...) I was thinking, wow, did she really swallow the liquid? (A7)

Thus, during the interviews there were divergences observed in the women's perceptions regarding to the professionals that cared for them during childbirth. The puerperal's report below identifies the professionals as someone who can 
contribute in reducing the anguish of this process that is permeated by diverse feelings.

They talked to me all the time (...) they talked a lot, they were the whole time very calm and that makes us feel calm too (A5).

Therefore, at the moment of separation it is necessary that the health professional includes the mother and her companion in the newborn's care, explaining each procedure to be performed, minimizing the anguish and fear, as it can be seen in this statement:

(...) Then, the young woman was explaining, that no, she was born with a little shortness of breath due to the childbirth (....) (A7)

In this study, it was also evidenced that not all the mothers had a positive perception regarding to the professional during the care. There were also reports of unsatisfaction with the labor process with complaints regarding the delay in the induction process and the care provided by the specific professionals.

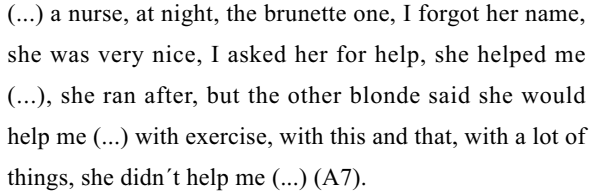

Regarding to the companion's presence at all times, the women reported feeling more confident and felt supported by their presence. As the following puerperal reveals:

And my companion was my husband, he kept talking to me all the time, asking if I was okay, if I was feeling something (...) (A6)

\section{Discussion}

The results presented are in the line of findings in other evident studies, emphasizing that when the unexpected outcome occurs, most of the mothers express fear, anxiety and insecurity regarding to the baby in such a fragile situation and the potential loss of their idealized baby until the moment of the birth. 14,15

Thus, the researchers affirm that only the families who experience such a life-threatening situation with their child, truly knows the extent of living in this anguishing experience. This feeling becomes intense from the moment of childbirth, especially when there is a previous adverse diagnosis or when the baby is premature. 15 Other researchers agree with this idea and describe that the mothers feel the fear of losing their child because they know that it is impossible to predict the outcome which may be positive or negative. 16

Thus, the ambivalent feelings experienced by these women during childbirth and the birth of their children were perceived. Both the expectation of having a child and the fear of losing a child are expressive elements that arise along with the fear of possible consequences to the baby regarding to being born prematurely or other comorbidities. 17

In this context, negative feelings can be lessen when the family is aware of the procedures that are going to be performed on their baby and then they begin to demystify the Unidade de Tratamento Intensivo Neonatal (UTIN) (Neonatal Intensive Care Unit), understanding its symbols and signs and they begin to see the sector as a safe place for them all.14 In this scenario, health professionals, especially the nursing team, need to accompany the family in the UTIN environment, encouraging them to co-participate in childcare, respecting their moments of stress, anxiety and anguish, allowing the bond between the mother and baby to be strengthened and to provide a safe, integral and humanized care. 18,19

Therefore, in cases where the bond between the mother and baby was interrupted right after childbirth, due to the baby's vitality instability, the contact should be stimulated by the professional until the baby's conditions are stabilized, by encouraging the mother to have daily contact care with the baby as at moment of bathing and feeding. Then the mother stops being a mere spectator and begins to participate in the baby's care. 19

Therefore, the care provided by the professionals at the moment of the separation can lessen the fears, anxieties and insecurities, and restore the motherchild bond by incorporating touch and skin-to-skin contact as soon as possible, reducing the abrupt mother and baby separation after childbirth. 16

Agreeing to these findings has been confirmed that the professional's attitude is fundamental in minimizing the mother's insecurity regarding to the separation of her child, since individual and integral care to the mother and baby should be offered along with an empathic approach with the aim of maintaining the new mother's well-being and of her newborn baby as well as involving the family in this process. 8

Thus, the childbirth process requires professional attention for the client, bond formation and communication skills are characteristics that may 
result in a less traumatic and painful childbirth, regardless to the type of childbirth, and thus, offering bond between the mother and the newborn regardless to diverse situations. ${ }^{8}$

However, according to the daily care of babies who are hospitalized right after childbirth, it was observed that even the multi-professional team provides guidance to the mothers and their families about the baby's conditions, the mothers' reactions may be different during this experience. 16

Regarding to the woman's choose of the companion's presence, the work of several authors corroborates the reports presented by the puerperals, and affirm that this support during the childbirth process contributes to the woman's physical and emotional well-being. The companion provides emotional support, comfort and encouragement, which reduce the feelings of loneliness, fear, anxiety and stress caused by the woman's vulnerability during childbrith. 21,22

Thus, experiencing this moment together with the companion or someone with whom the woman has an affective bond will strengthens their relationship. $23-25$

In order to guarantee these benefits, Law No. 11108 was enacted in 2005, which establishes that the healthcare services at the Sistema Único de Saúde (SUS) (National Health System) or the private health system are obliged to allow the presence of a companion, chosen by the woman during childbirth and the immediate postpartum period. 26

\section{Final considerations}

From maternal statements it was possible to observe the contradictions and challenges experienced by the mothers who experience the mother-child separation

\section{References}

1. Santos KD, Motta IF. O significado da maternidade na trajetória de três jovens mães: um estudo psicanalítico. Estud Psicol. (Campinas). 2014; 31 (4): 517-25.

2. Strapasson MR, Nedel MNB. Puerpério imediato: desvendando o significado da maternidade. Rev Gaúch Enferm. 2010; 31 (3): 521-8.

3. Rosa R, Liceski BG, Marisa MM, Martins FE, Siebert ERC, Martins NM. Mãe e filho: os primeiros laços de aproximação. Mãe e filho: os primeiros laços de aproximação. Esc Anna Nery. 2010; 14 (1): 105-12.

4. Moore ER, AndersonGC, Bergman N. Contato piel-apiel temprano para las madres y sus recien nascidos sanos (Revisison Cochrane traducida). La Biblioteca Cochrane Plus. 2007; n. 1: 1-60. and who experienced so many diverse feelings, such as joy due to the arrival of the child and the fear of losing their child; the desire to embrace them and to stay with them and to also understand the need for the child to be taken away.

Therefore, it is the professionals' responsibilities to minimize the effects and traumas of the early mother and child separation and promote skin-toskin contact and mother and baby attachment. Including the companion in this process can bring a positive impact for these women who experienced these feelings, once the support from the professionals are linked to the family members, this can make the mother feel safe and bring greater tranquillity at the moment of anguish, fear and sadness.

The feelings and experiences reported by the women in the separation situation should be taken in consideration by the health professionals during the care so that they can meet their demands and thus lessen the traumas that are caused by the motherchild separation.

We hope that the results found in this study may increase the quality of care for women who are separated from their child in the postpartum period, as well as guiding the professionals to care for the woman and the newborn in relation to their real necessities.

On the other hand, further studies that address this issue are necessary in order to sustain and broaden the discussion which may lead to changes in this practice. We suggest that the theme should be routinely discussed by professionals in the area, and that it takes part of their academic training.

5. Brasil. Ministério da Saúde. Portaria n ${ }^{0} 371$, de 7 de Maio de 2014. Institui diretrizes para a organização da atenção integral e humanizada ao recém-nascido (RN) no Sistema Único de Saúde(SUS). Diário Oficial da União, Brasília, DF, 08 maio 2014: Seção 1. [acesso em 1 fev 2018]. Disponível em: http://bvsms.saude.gov.br/bvs/saudelegis/ sas/2014/prt0371_07_05_2014.html

6. Matos TA, Souza MS, Santos EKA, Velho MB, Seibert ERC, Martins NM. Contato precoce pele a pele entre mãe e filho: significado para mães e contribuições para a enfermagem. Rev Bras Enferm. 2010; 63 (6): 998-1004.

7. Andrade RD, Santos JS, Maia MAC, Mello DF. Fatores relacionados à saúde da mulher no puerpério e repercussões na saúde da criança. Esc Anna Nery. 2015; 19 (1): 181-6. 
8. Souza CM, Ferreira CB, Barbosa NR, Marques JF. Equipe de enfermagem e os dispositivos de cuidado no trabalho de parto: enfoque na humanização. Rev Pesq Cuid Fundam. 2013; 5 (4): 743-54

9. Minayo MCS. O desafio do conhecimento: pesquisa qualitativa em saúde. 10 ed. São Paulo: Hucitec; 2010.

10. Hospital Sofia Feldman. O hospital [internet]. Belo Horizonte: HSF, 2015 [acesso em 1 fev 2018]. Disponível em: http://www.sofiafeldman.org.br/o-hospital/

11. Fontanella BJB, Luchesi BM, Saidel MGB, Ricas J, Turato ER, Melo DG. Amostragem em pesquisas qualitativas proposta de procedimentos para constatar saturação teórica. Cad Saúde Pública. 2011; 27 (2): 389-94.

12. Bardin L. Análise de conteúdo. 70 ed. Lisboa (PT): LDA; 2009.

13. Brasil. Ministério da Saúde. Diretriz Nacional de Assistência ao Parto Normal. Relatório de Recomendação: Conitec - Comissão Nacional de Incorporação de Tecnologias do SUS. Brasília, DF, 2016. [acesso em 1 fev 2018]. Disponível em: http://conitec.gov.br/images Consultas/2016/Relatorio_Diretriz-PartoNormal_CP.pdf

14. Cruz ARM, Oliveira MMC, Cardoso MVLML, Lúcio IML. Sentimentos e expectativas da mãe com filho prematuro em ventilação mecânica. Rev Eletrônica Enferm. 2010; 12 133-9.

15. Melo RCJ, Souza IEO, Paula CC. O sentido do ser-mãeque-tem-a-possibilidade-de-tocar-o-filho-prematuro na unidade intensiva: contribuições para a enfermagem neonatal. Esc Anna Nery. 2012; 16 (2): 219-26.

16. Botêlho SM, Boery RNSO, Vilela ABA, Santos WS, Pinto LS, Ribeiro VM, Machado JC. O cuidar materno diante do filho prematuro: um estudo das representações sociais. Rev Esc Enferm. USP. 2012; 46 (4): 929-34.

17. Araújo BBM, Rodrigues BMRD. Alojamento de mães de recém-nascido prematuro. Esc Anna Nery Rev Enferm. 2010; 14 (2): 284-92.

18. Sousa FCP, Montenegro LC, Goveia VR, Corrêa AR, Rocha PK, Manzo BF. A participação da família na segurança do paciente em unidades neonatais na perspectiva do enfermeiro. Texto Contexto Enferm. 2017; 26 (3): e01180016.
19. Brasil. Ministério da Saúde. Secretaria de Atenção à Saúde. Departamento de Ações Programáticas Estratégicas. Atenção à saúde do recém-nascido: guia para os profissionais de saúde - 2. ed. - Brasília, DF, 2012. [acesso em 1 fev 2018]. Disponível em: http://bvsms.saude.gov.br/bvs/ publicacoes/atencao_saude_recem_nascido_v1.pdf

20. World Health Organization (WHO); United Nations Children's Fund (UNICEF). Baby-friendly hospital initiative: revised, updated and expanded for integrated care. Section 1. Background and Implementation. Geneva; 2009. [acesso em 1 fev 2018]. Disponível em: http://apps.who.int/iris/bitstream/10665/43593/1/97892415 94967_eng.pdf

21. Dodou HD , Rodrigues DP , Guerreiro EM , Guedes MVC, Lago PN , Mesquita NS. A contribuição do acompanhante para a humanização do parto e nascimento: percepções de puérperas. Esc. Anna Nery. 2014; (18) 2 : 262-9

22. Jardim DMB. Pai-acompanhante e a sua compreensão sobre o processo de nascimento do filho [dissertação]. Belo Horizonte: Universidade Federal de Minas Gerais; 2009.

23. Missonnier S, Solis-Ponton L. Parentalidad y embarazo: convertirse en madre, convertirse en padre: las interaciones entre los padres y su hijo antes del nacimiento. In: SolisPonton L, organizador. La parentalidad: desafíos para el tercer milênio. México: Manual Moderno; 2004. p. 75-92.

24. Hodnett ED, Simon G, Justus HG, Carol S. Continuous support for women during childbirth. Cochrane Database of Systematic Reviews. 2012; p. 1-173.

25. M, Hollywood E. The lived experiences of fathers of a premature baby on a neonatal intensive care unit. J Neonatal Nurs. 2011; 17 (1): 32-40.

26. Brasil. Lei $\mathrm{n}^{\mathrm{o}} 11.108$ de 7 de abril de 2005 . Altera a Lei $\mathrm{n}^{\circ}$ 8.080 , de 19 de setembro de 1990 , para garantir às parturientes o direito à presença de acompanhante durante o trabalho de parto, parto e pós-parto imediato, no âmbito do Sistema Único de Saúde - SUS. Diário Oficial da União [periódico na internet], Brasília (DF). 7 abr 2005. Disponível em: http://www.planalto.gov.br/ccivil_03/ Ato2004-2006/2005/Lei/L11108.htm. 